\title{
An investigation into factors causing delays in highway construction projects in iraq
}

\author{
Bevian I. Al Hadithi \\ Building and Construction Engineering Department/ University of Technology, Baghdad, Iraq
}

\begin{abstract}
The highways sector is a prominent sector in any country's economy because of its impact on the well-being and safety of its citizens. The transport sector has an impact on social improvement and investment in the nation on the illustration that allows access to markets, production, jobs, health and other social services. This study investigates the causes of delay of highway construction projects in Iraq, which is frequent occurrence. Data was collected using questionnaires which were distributed to the key project participants; contractors, owners and consultants. The data were analyzed using the Frequency index and Spearman's rank correlation. The top seven causes of project delays were observed to be political decisions and political realities, the economic crisis of the country, delays in materials test of and obtaining the results, delay in monthly payments of contractor, failure treatment of the delays when implementing the project, the effects of weather, rain and high temperatures, delay in activities during implementation. It is recommended to establish an appropriate number of laboratories and adopt the field laboratory mechanism for the external and remote screens. Owners should give special attention to pay progress payment to contractors on time. The competent contractor who has prior experience in implementing the high projects should be selected. The contractor must take into consideration the weather conditions when preparing the time plan necessary to implement the project. The project management should identify these reasons and deal with them quickly in order to reduce the total delay of the project.
\end{abstract}

\section{Introduction}

A lot of construction projects in the world and Iraq in particular are suffering from delay in implementation. It could say that a project that does not suffer from delays is rarely found.

One of the recurring problems in the construction industry is

the issue of delay, which negatively affects the success of the project in terms of time, cost and quality [1]. Delay has a negative effect on owners, contractors and consultants in terms of growth in adversarial relationships, mistrust, litigation, arbitration, cash-flow problems and a general feeling of trepidation toward one another [2]. Project value was found to have a negative correlation with time loss due to the demonization indicating that as project size increases time loss decreases [3]. Delay is mostly common in the traditional type of contracts in which the contract is awarded to the lowest bidder.

This procurement method is mostly practiced in developing

Countries. Ensuring that the project is delivered on time is one of the most significant needs of the clients in the construction industry [4]. The number of projects delayed in Iraq for the period 2006-2007, according to the sample of the research, (571) of the total (1993) project. School projects ranked first with a response rate of $27 \%$, followed by public buildings projects with $24 \%$ response and road projects with $21 \%$ response. Note that this is due to the large number of projects implemented from these types compared to the projects of electricity and transport, for example, which received the lowest rates [5]. In Iraq, according to a survey finding that many projects suffer from a great deal of delay and due to specific factors, many projects were temporarily or permanently abandoned during the political crisis between 2003 and 2014.This factor escalates disputes to be settled by litigation process. The parties involved in the project use litigation as a last resort to settle disputes [6].

\section{Literature review}

A total of 130 general construction projects was studied in Jordan, which were built during the period 1990-1997. The study found that the main reasons were related to thedisinr or user changes, weather, site conditions, delayed births, economic conditions and increases in quantities[7].Al-Najjar (2008) concluded that the most important factors causing time overruns in building construction projects in the Gaza Strip as perceived by contractors were: strikes, Israeli attacks and border closures, lack of materials in the markets, shortage of construction materials at the site, delays of material deliveries to site, cash shortages during construction, poor 
site management, poor economic conditions (currency, inflation rate, etc.), Shortage of equipment and tools on site, and owner delay in freeing the contractor payments for completing work[8].Kasimu \& Abubakar investigate the causes of delay in the Nigeria construction industry. The survey method was adopted for this work through questionnaire distributed to contractors, clients and consultants in the construction industry in Nigeria.The results obtained from ranking analysis show that , improper planning, lack of communication, design errors and shortage of supply is the major cause of delay[9]. Also Surveys were conducted in Vietnam to identify the causes of delay in government projects and to find solutions for dealing with the delay. The five most highly ranked delay factors were: information delays and lack of information exchange between the parties; incompetent owner; incompetent supervision consultant; incompetent contractor; and difficulties in financing project by owner[10].

Delays in road construction projects in Kenya were studied, and the questionnaire was distributed to contractors and consultants.Data were collected and analyzed using the relative significance index and Spearman rank. The payment by the client, the slow decision-making process and bureaucracy in the client organization, inadequate planning, scheduling, and arbitrage are the five main causes of project delays.Client improves their financial management systems so that they can pay contractors in a timely manner, reducing bureaucracy and red tape in client organizations to accelerate slow decision making was one of the main recommendations of this study[11]. The causes of delayed road construction in Egypt were analyzed, a survey questionnaire was distributed. The relative importance index (RII) is calculated according to the highest values, the top 20 and the twenty lowest reasons for the construction projects in Egypt are determined.The test results reveal a good correlation of causes and groups between contractors and site/design engineers and between consultants and site design engineers and a somewhat low correlation between contractors and consultants. So there is no root cause that can be taken for granted to be most or least effective delay causes. The Proposed model for predicting actual road construction project duration was developed[12].

Emphasis has been placed on delays in donor-funded road projects that have become imperative, and an endemic problem in Sri Lanka is hindering the effective use of external assistance to these projects. The main factors that led to the delay were identified. An alarming situation had been revealed that, during the execution process, increase in quantities had a significant effect on the project time and accounted for about $56 \%$ of the delays. The errors and omissions in detail design, changes in specifications and scope, were the most prevalent sources of quantity increases. Further, during the planning process, the procurement of work activities was delayed by $23 \%$, mainly due to shortcomings in contract documents and approvals from relevant agencies[13]. Several sample projects implemented over the years 2000-2008 have been analyzed. All projects were managed by the same organization and taken from the Ministry of Rural Works and Public Works of Jordan. By reviewing the literature, 19 factors have been identified which are causing delays in road construction projects. Land and weather conditions are the most important factors affecting time and cost in road construction projects in Jordan[14].A study was conducted to investigate the time performance of road construction projects in the West Bank in Palestine to identify the causes of delay and their severity according to contractors and consultants through a questionnaire survey. The field survey included 34 contractors and 30 consultants. A total of 52 causes of delay were identified during the research. The survey concluded that the top five severe delay causes are political situation, segmentation of the West Bank and limited movement between areas, award project to lowest bid price, payment delay by owner, and a shortage of equipment[15].

\section{Justification for research}

After interviewing project managers in companies specialized in the implementation of highway projects construction in Iraq it was concluded that there is a big delay happening in these projects.

Studies on the implementation of high construction projects in Iraq focus on the cost side without consideration of the factors Causing Delays in these projects

\section{Objectives}

The main objectives of this study include the following: 1- To identify the causes of delays in highway construction projects in Iraq based on their frequent occurrence

2- To study the differences in views of the three major parties in any construction project, namely, owners, contractors and consultants.

\section{Research methodology}

The objectives of the research were achieved through a literature review. The field survey included 47 respondents made up to 28 contractors, 6 consultants and 13 owners were represented by the General Authority for Iraqi Roads and Bridges. The questionnaire was divided into three parts. The first included education level information and years of experience Fig (1), Fig (2). The second part, which is the most important, focused on causes of construction delay.Questionnaires were delivered to participants in person; in addition an electronic questionnaire was used because of the shortage of number of questionnaires retrieved, which is one of the difficulties encountered in this study.

The respondents were requested to indicate their response to the frequency of occurrence of 64 well-recognized construction delay factors. These causes were categorized into the following seven groups of factors:

- Contractor

- Owner

- Consultant

- Materials 
- External factors

- Equipment \&labor

- Related to the project

The questionnaire fundamentally based on Likert's scale of 5 ordinal measures from 1 to 5 according to the level of their frequent occurrence:
(5) = always
(4) $=$ often
(3) $=$ sometimes
(2) $=$ rarely
(1) $=$ never happened

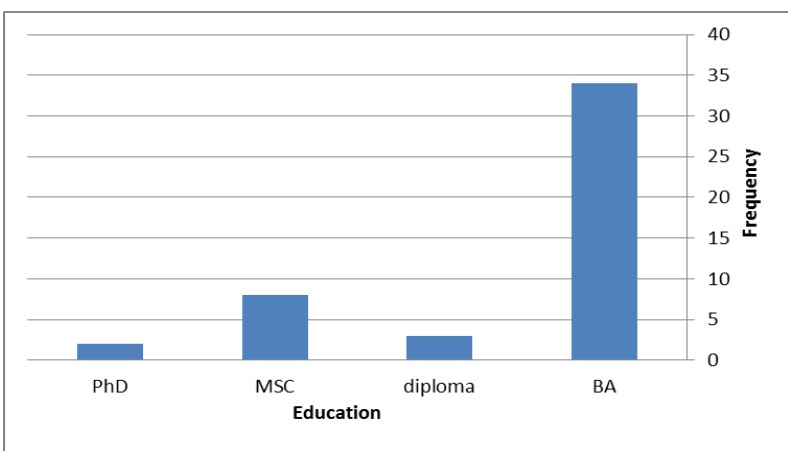

Fig. 1. Level of education of questionnaire

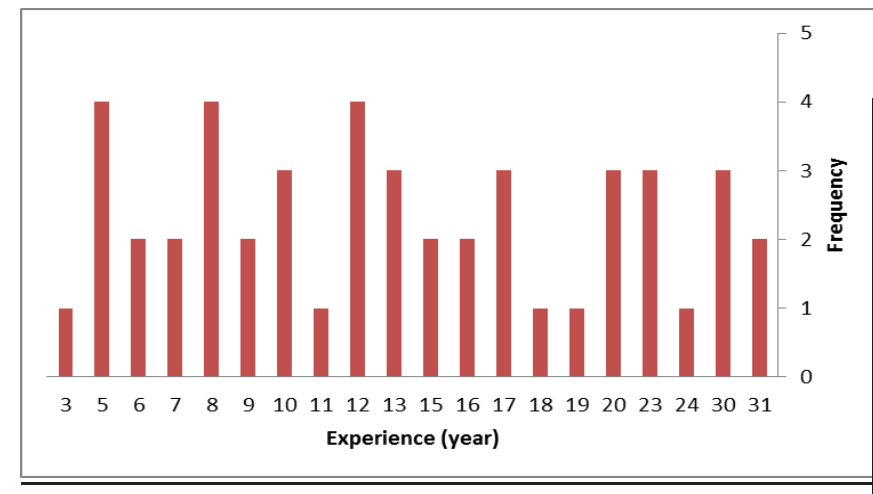

Fig. 2. Experience years of questionnaire

\section{Consistency coefficient for the questionnaire}

To calculate the consistency coefficient for the questionnaire based on their frequency of occurrence,using the CronbachAlpha equation, which was implemented using the Statistical Package for Social Sciences (SPSS). The results are shown in the following table:

The results show that Cronbach's coefficient for all items equal (0.923). This range is considered high; the result ensures the reliability of the questionnaire [16].

\section{Data analysis}

Histograms have been used to identify the delay factors that are frequent occurrence in the implementation of highway projects in Iraq from the point of view of contractors, employers and consultants, and the collected data were analyzed through the Frequency Index:
A formula is used to rank the causes of delay, based on frequency of occurrence as identified by the participants.

$$
\text { Frequency Index }(F . I)(\%)=\Sigma a(n / N) * 100 / 5
$$

Where (a) is the constant expressing weight given to each response (range from 1 to 5), $\mathrm{n}$ is the frequency of the response and $\mathrm{N}$ is the total number of responses.

Spearman's rank correlation was used to show the level of agreement between two parties.

$$
r s=1-6 \Sigma d^{2} /\left(n^{3}-n\right)
$$

Where 'rs' is the Spearman'srank correlation coefficient; ' $d$ ' is the difference in ranking between any two parties; and ' $n$ ' is the number of factors. The correlation coefficient varies between +1 and -1 , where +1 means a perfect positive relationship (agreement), while 1 means a perfect negative relationship (disagreement). Sample estimates of correlation close to unity in magnitude mean good correlation, while values near zero indicate little or no correlation.

According to the contractors' opinion, the results of the delay factors which has the effect on the implementation of highway projects in Iraq are shown in Table (1), and Fig 3,4,5and 6 respectively.

Table (1) results of the delay factors according to the contractors' opinion

\begin{tabular}{||l|c|c|}
\hline \multicolumn{1}{|c|}{ Delay factor } & $\begin{array}{c}\text { Level of } \\
\text { frequent }\end{array}$ & $\begin{array}{c}\text { Percentages } \\
\%\end{array}$ \\
\hline $\begin{array}{l}\text { the economic crisis of the } \\
\text { country }\end{array}$ & always & 35.7 \\
\hline $\begin{array}{l}\text { Delay in monthly payments } \\
\text { of the contractor }\end{array}$ & $\begin{array}{c}\text { often } \\
\text { happening }\end{array}$ & $50 \%$ \\
\hline $\begin{array}{l}\text { The effects of weather, rain } \\
\text { and high temperatures }\end{array}$ & $\begin{array}{c}\text { often } \\
\text { happening }\end{array}$ & $50 \%$ \\
\hline $\begin{array}{l}\text { Delays in materials test of } \\
\text { and obtaining the results }\end{array}$ & $\begin{array}{c}\text { often } \\
\text { happening }\end{array}$ & $46.4 \%$ \\
\hline
\end{tabular}

The overall top six delay factors which are always happening in the implementation of highway projects in Iraq, are shown in Table (2), and Fig 7, 8, 9,10,11 and 12 respectively. 
Table (2) results of the delay factors according to the owners'

\begin{tabular}{|c|c|c|}
\hline Delay factor & $\begin{array}{l}\text { Level of } \\
\text { frequent }\end{array}$ & $\begin{array}{c}\text { Percentages } \\
\%\end{array}$ \\
\hline the economic crisis of the country & always & $46.2 \%$ \\
\hline $\begin{array}{l}\text { Ineffective inspection of equipment } \\
\text { takes }\end{array}$ & & $46.2 \%$ \\
\hline $\begin{array}{l}\text { Not to provide services to workers } \\
\text { through the implementation of external } \\
\text { roads }\end{array}$ & always & $38.5 \%$ \\
\hline $\begin{array}{l}\text { Services for underground construction } \\
\text { such as telephone and electricity lines, } \\
\text { water pipes, oil pipelines, and rainwater } \\
\text { pipes }\end{array}$ & always & $38.5 \%$ \\
\hline $\begin{array}{l}\text { Deficiency of skilled and unskilled } \\
\text { laborers, take }\end{array}$ & always & $30.8 \%$ \\
\hline $\begin{array}{l}\text { Changes in site topography after design, } \\
\text { take }\end{array}$ & always & $30.8 \%$ \\
\hline
\end{tabular}

The overall top five delay factors which always happening in the implementation of highway projects in Iraq, according to the Consultants' opinion are shown in Table (3), and Fig 13,14,15,16 and 17 respectively.

Table (3) results of the delay factors according to the Consultants' opinion

\begin{tabular}{|l|c|c|}
\hline \multicolumn{1}{|c|}{ Delay factor } & Level of frequent & $\begin{array}{c}\text { Percentages } \\
\%\end{array}$ \\
\hline $\begin{array}{l}\text { the economic crisis of } \\
\text { the country }\end{array}$ & always & $100 \%$ \\
\hline $\begin{array}{l}\text { Political decisions and } \\
\text { political realities }\end{array}$ & always & $66.7 \%$. \\
\hline $\begin{array}{l}\text { Cash flow problems } \\
\text { faced by the contractor }\end{array}$ & always & $50 \%$. \\
\hline $\begin{array}{l}\text { Changes in the } \\
\text { contract by the owner } \\
\text { during the } \\
\text { construction process }\end{array}$ & always & $50 \%$. \\
\hline $\begin{array}{l}\text { Ineffective inspection } \\
\text { of equipment }\end{array}$ & always & $50 \%$. \\
\hline
\end{tabular}

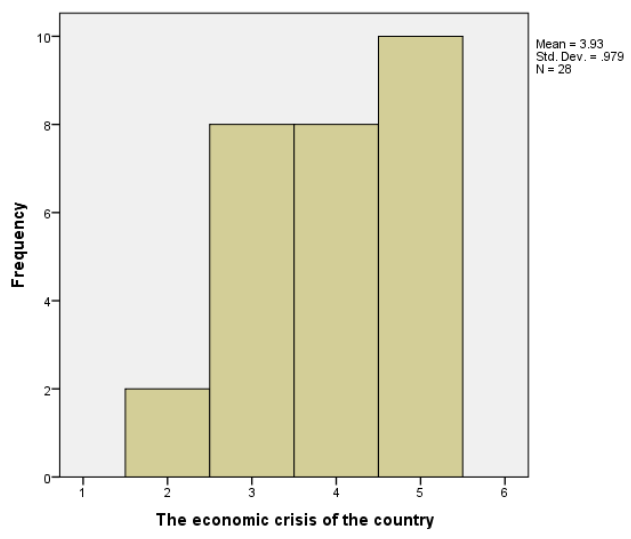

Fig (3) frequency occurred of the economic crisis in the country in the projects according to the contractor's opinion

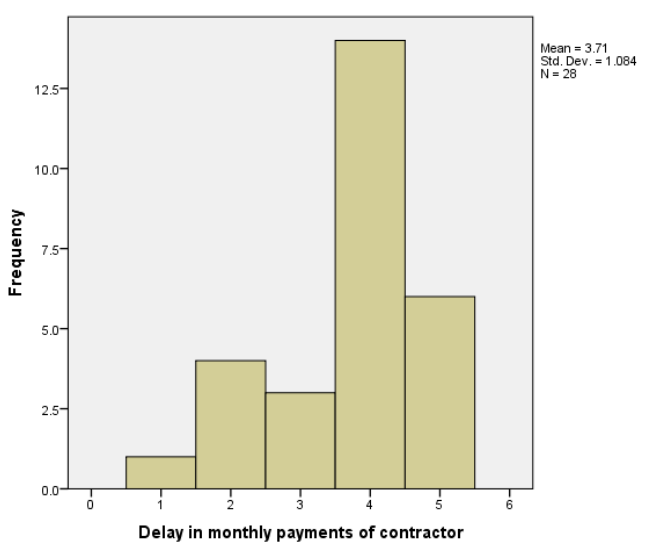

Fig (4) the frequency of the delay in monthly payments of contractor

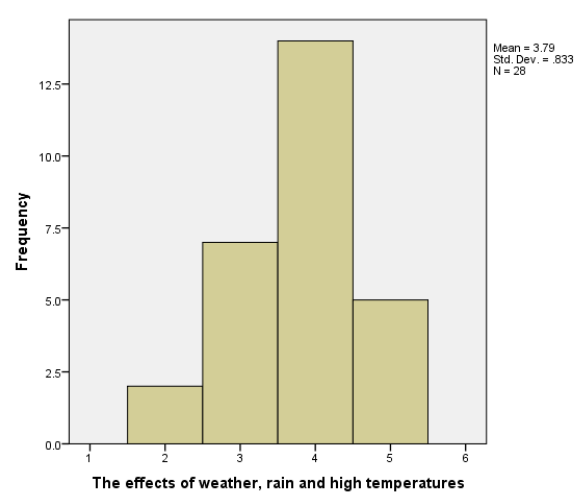

Fig (5) the frequency of the effects of weather, rain and high temperatures 


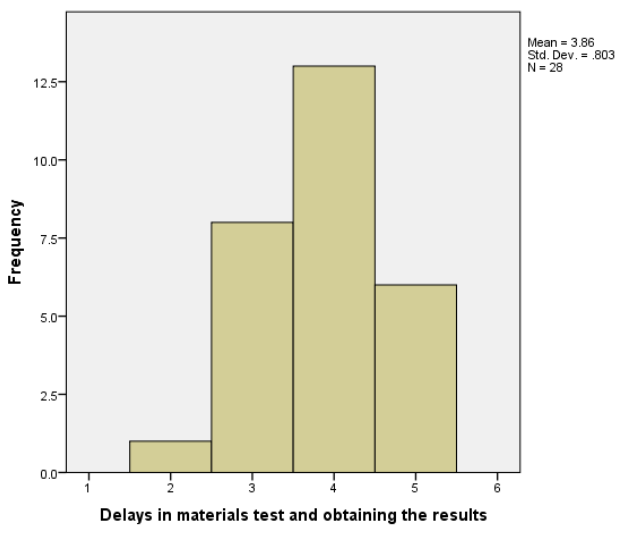

Fig (6) the frequency of delays in materials test of and obtaining the results

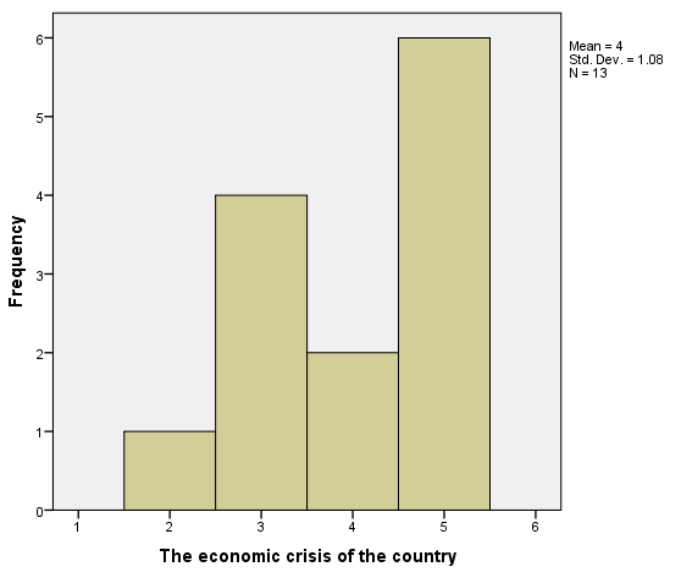

Fig (7) frequency occurred of the economic crisis in the country in the projects according to the owners' opinion

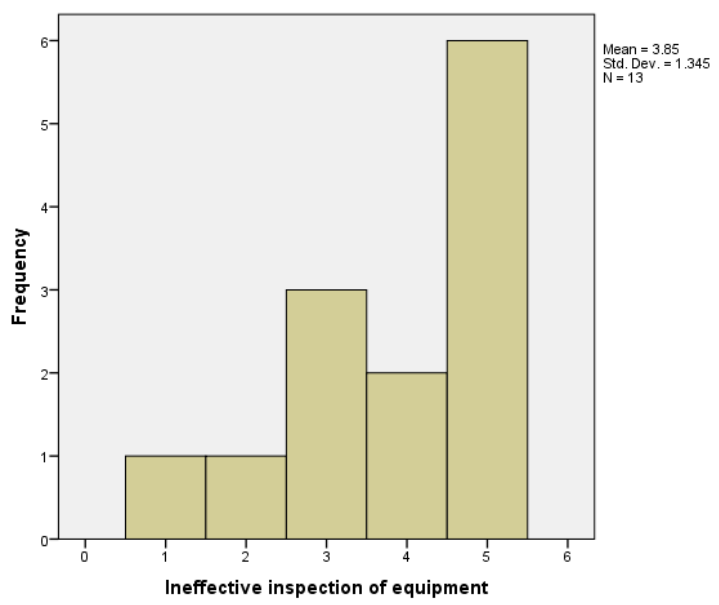

Fig (8) frequency occurred of the Ineffective inspection of equipment

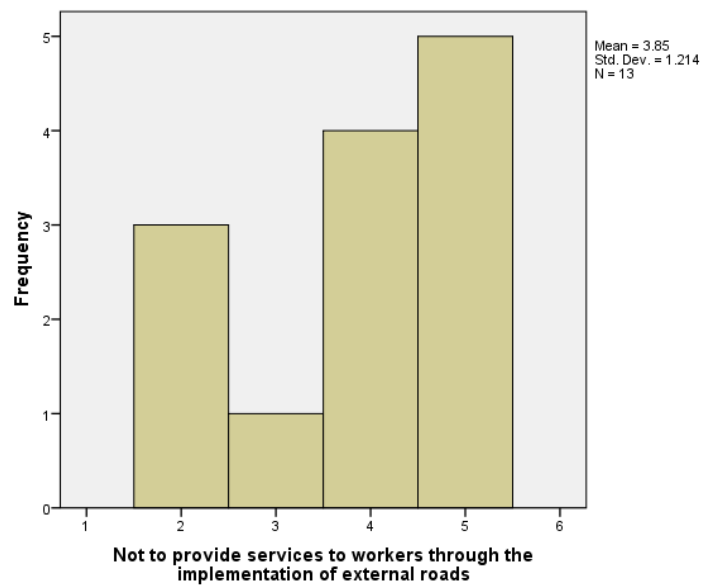

Fig (9) frequency occurred not to provide services to workers through the implementation of external roads

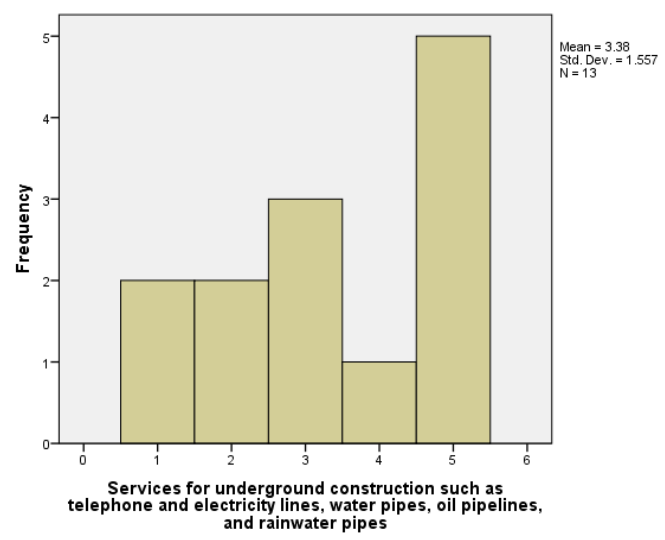

Fig (10) frequency occurred Services for underground construction such as telephone electricity lines etc.

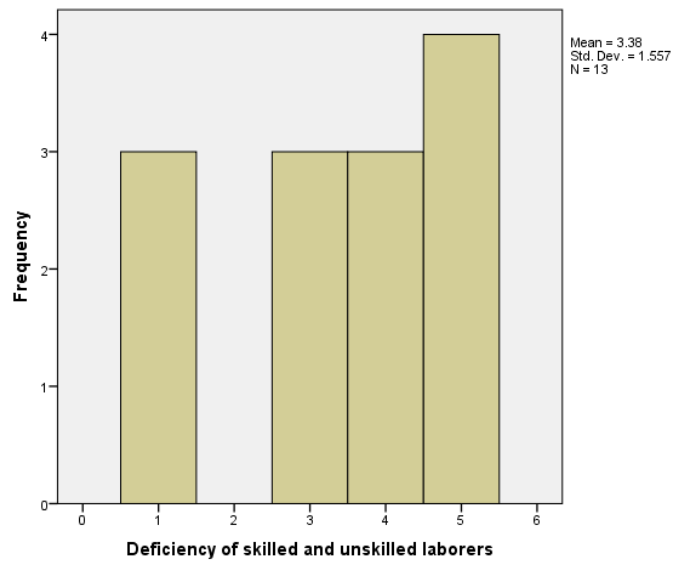

Fig (11) frequency occurred Deficiency of skilled and unskilled laborers 


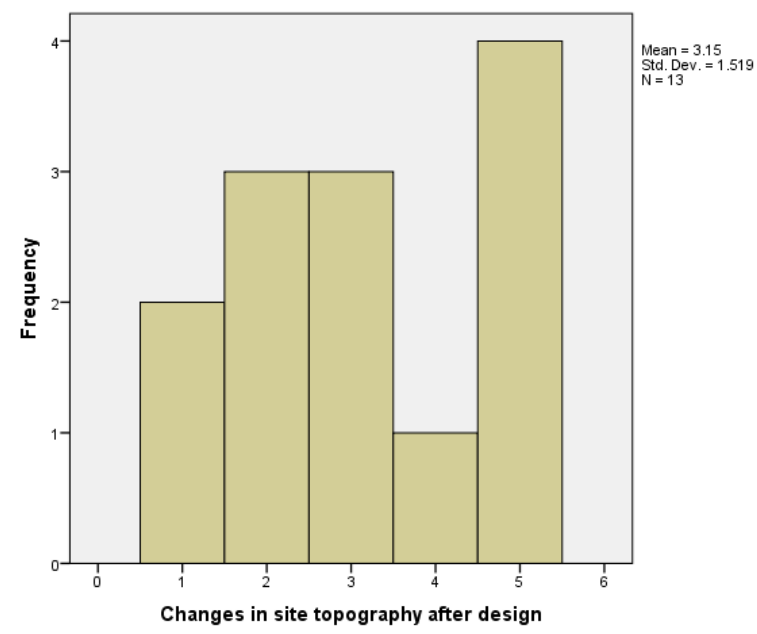

Fig (12) frequency occurred Changes in site topography after

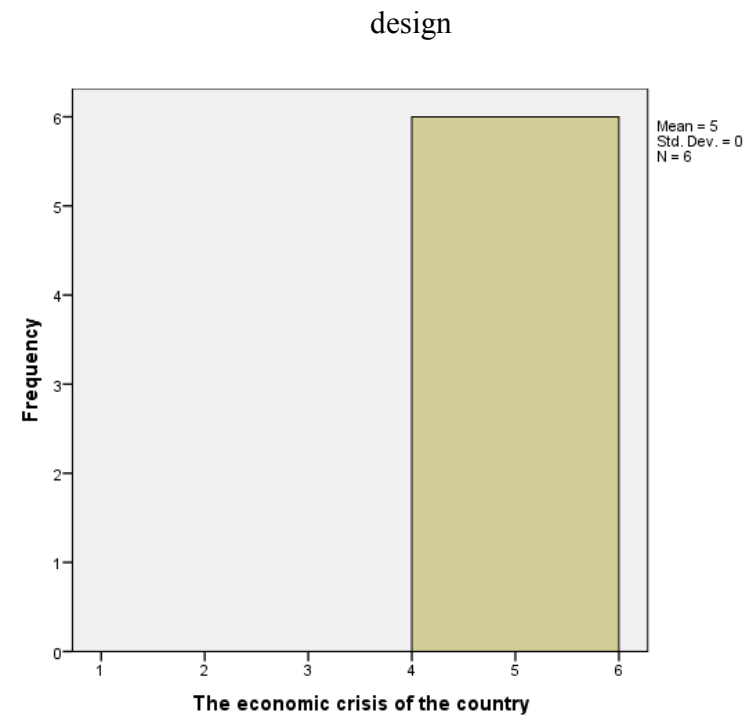

Fig (13) frequency occurred of the economic crisis in the country in the projects

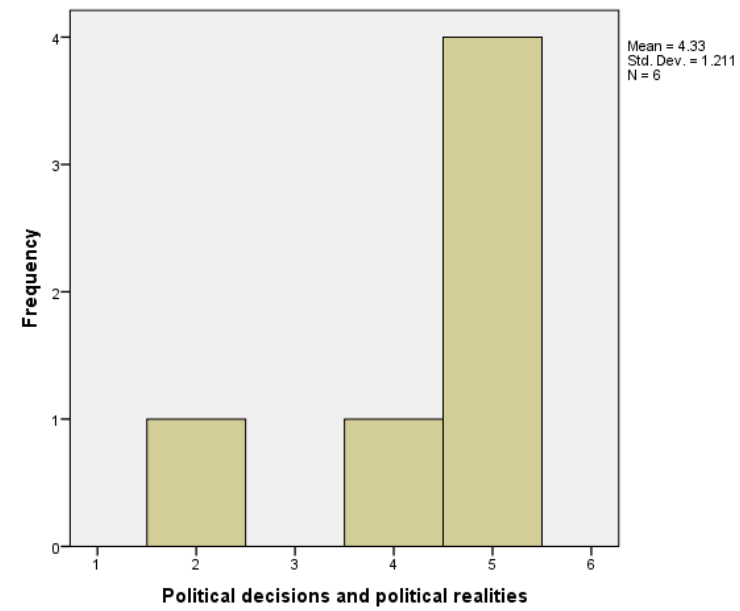

Fig (14) the frequency of the political decisions and political realities

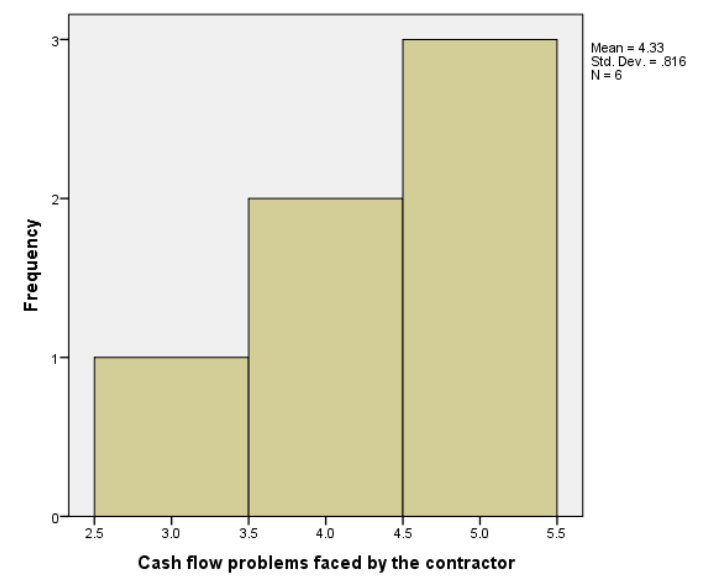

Fig (15) the frequency of Cash flow problems faced by the contractor

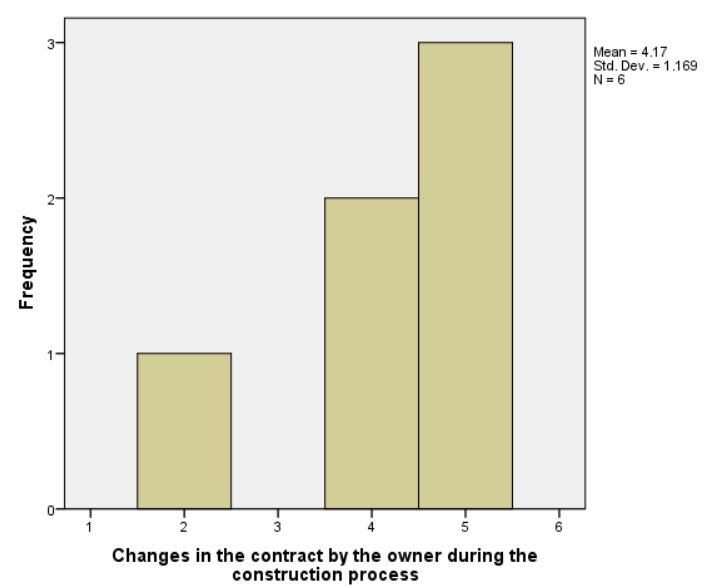

Fig (16) the frequency of Changes in the contract by the owner during the construction process

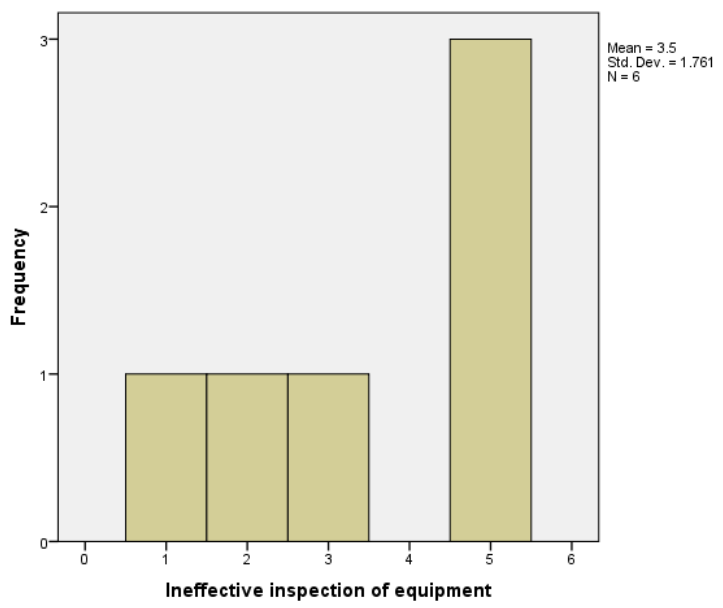

Fig (17) the frequency of ineffective inspection of equipment in the projects 


\subsection{The delay causes from the contractor's and owner's point of view}

Table 4shows all causes of delay and frequency of occurrence of each reason and its arrangement from the point of view of the contractor and the owner.

The overall top seven causes of delay identified by both consultants and contractors were:

Political decisions and political realities (F.I=69.79), The economic crisis of the country (F.I=68.94), Delays in materials test of and obtaining the results (F.I=68.94), Delay in monthly payments of contractor (F.I=65.96), Failure treatment the delays when implementing the project (F.I=67.66), The effects of weather, rain and high temperatures (F.I=65.53),Delay in activities during implementation (F.I=61.28).The Spearman's rank correlation coefficient between the contractors and owners was calculated and found to be 0.57 which showed that there was a positive correlation between the views of them.

Table 4 Delay causes from the contractor and owner point of view

\begin{tabular}{|c|c|c|}
\hline & $\begin{array}{c}(\text { F. I) } \\
(\%)= \\
\Sigma a \\
(\mathbf{n} / \mathbf{N}) * \\
100 / 5\end{array}$ & RANK \\
\hline \multicolumn{3}{|l|}{$\begin{array}{l}\text { Reasons related to the } \\
\text { Contractor }\end{array}$} \\
\hline Delay in delivering the site & 50.21 & 41 \\
\hline $\begin{array}{l}\text { Deficiencies in bidding by } \\
\text { contractors/causing calling them } \\
\text { to clarify it in the stage of the } \\
\text { award of the contract }\end{array}$ & 47.23 & 50 \\
\hline $\begin{array}{l}\text { Failure treatment the delays when } \\
\text { implementing the project }\end{array}$ & 65.53 & 5 \\
\hline $\begin{array}{l}\text { Delay in the consent of the owner } \\
\text { of the land to expand the road } \\
\text { through its }\end{array}$ & 48.51 & 47 \\
\hline $\begin{array}{l}\text { Poor Relationship between the } \\
\text { contractor and consultant }\end{array}$ & 46.38 & 53 \\
\hline $\begin{array}{l}\text { Cash flow problems faced by the } \\
\text { contractor }\end{array}$ & 58.72 & 11 \\
\hline $\begin{array}{l}\text { Inflation in material prices on the } \\
\text { market }\end{array}$ & 45.96 & 56 \\
\hline $\begin{array}{l}\text { Late deliveries of materials from } \\
\text { suppliers }\end{array}$ & 46.38 & 53 \\
\hline Supplier inefficiency & 49.79 & 42 \\
\hline Claims problems & 55.32 & 19 \\
\hline $\begin{array}{l}\text { Delay in activities during } \\
\text { implementation }\end{array}$ & 61.28 & 7 \\
\hline Cost estimates are not accurate & 60.43 & 10 \\
\hline Delay penalties & 48.51 & 47 \\
\hline \multicolumn{3}{|l|}{ Reasons related to the owner } \\
\hline $\begin{array}{l}\text { Changes in the contract by the } \\
\text { owner during the construction } \\
\text { process }\end{array}$ & 53.19 & 28 \\
\hline Delay in monthly payments of & 65.96 & 4 \\
\hline
\end{tabular}

\begin{tabular}{|c|c|c|}
\hline contractor & & \\
\hline $\begin{array}{l}\text { Problems in purchasing land } \\
\text { belonging to citizens }\end{array}$ & 53.62 & 27 \\
\hline $\begin{array}{l}\text { Misunderstandings with suppliers } \\
\text { and subcontractors }\end{array}$ & 51.49 & 33 \\
\hline $\begin{array}{l}\text { Insufficient and incomplete } \\
\text { feasibility studies }\end{array}$ & 57.02 & 15 \\
\hline Design problems & 61.28 & 7 \\
\hline \multicolumn{3}{|l|}{$\begin{array}{l}\text { Reasons related to the } \\
\text { consultant }\end{array}$} \\
\hline Error in site surveys & 56.60 & 16 \\
\hline $\begin{array}{l}\text { Error in approving the drawing by } \\
\text { the consultant }\end{array}$ & 56.60 & 16 \\
\hline $\begin{array}{l}\text { Inadequate authority for decision- } \\
\text { making by consultant }\end{array}$ & 51.91 & 32 \\
\hline Mistakes in Consultant drawings & 54.04 & 25 \\
\hline Weak consultant experience & 51.06 & 36 \\
\hline $\begin{array}{l}\text { Insufficient site information for } \\
\text { the consultant }\end{array}$ & 57.45 & 14 \\
\hline The inaccuracy of dimensions & 55.32 & 19 \\
\hline \multicolumn{3}{|l|}{ Reasons related to the materials } \\
\hline $\begin{array}{l}\text { Shortage of materials during } \\
\text { implementation }\end{array}$ & 52.77 & 29 \\
\hline $\begin{array}{l}\text { Using materials does not conform } \\
\text { to specifications }\end{array}$ & 54.47 & 23 \\
\hline $\begin{array}{l}\text { Unexpected and repeated } \\
\text { adjustments in material } \\
\text { specifications during construction }\end{array}$ & 51.06 & 36 \\
\hline Material quality problems & 45.96 & 56 \\
\hline $\begin{array}{l}\text { Weakness in the site materials } \\
\text { management }\end{array}$ & 51.06 & 36 \\
\hline Rise in the prices of materials & 54.89 & 22 \\
\hline $\begin{array}{l}\text { Insufficient materials at the } \\
\text { beginning of the project, causing } \\
\text { delays }\end{array}$ & 51.49 & 33 \\
\hline $\begin{array}{l}\text { Do not put the material in its } \\
\text { proper place, causing difficulty in } \\
\text { transporting it inside the site }\end{array}$ & 50.64 & 39 \\
\hline Damage of materials & 48.51 & 47 \\
\hline $\begin{array}{l}\text { Disposal of road construction } \\
\text { waste }\end{array}$ & 51.49 & 33 \\
\hline $\begin{array}{l}\text { Delays in a materials test of and } \\
\text { obtaining the results }\end{array}$ & 67.66 & 3 \\
\hline \multicolumn{3}{|l|}{ Causes of external delay } \\
\hline $\begin{array}{l}\text { The effects of weather, rain and } \\
\text { high temperatures }\end{array}$ & 65.53 & 5 \\
\hline Low temperatures & 47.23 & 50 \\
\hline $\begin{array}{l}\text { Political decisions and political } \\
\text { realities }\end{array}$ & 69.79 & 1 \\
\hline $\begin{array}{l}\text { The economic crisis of the } \\
\text { country }\end{array}$ & 68.94 & 2 \\
\hline \multicolumn{3}{|l|}{$\begin{array}{l}\text { Reasons for labor and } \\
\text { equipment }\end{array}$} \\
\hline $\begin{array}{l}\text { Deficiency of skilled and } \\
\text { unskilled laborers }\end{array}$ & 55.32 & 19 \\
\hline Poor manpower productivity & 60.85 & 9 \\
\hline Injuries on site & 40.85 & 62 \\
\hline Labor strikes & 35.32 & 64 \\
\hline Absence of equipment & 48.94 & 46 \\
\hline
\end{tabular}




\begin{tabular}{|l|c|c|}
\hline Delayed delivery of equipment & 49.79 & 42 \\
\hline Shortage in equipment availability & 52.34 & 31 \\
\hline Insufficiency of operators & 54.47 & 23 \\
\hline $\begin{array}{l}\text { No adequate spaces for temporary } \\
\text { and permanent equipment }\end{array}$ & 45.11 & 61 \\
\hline $\begin{array}{l}\text { Ineffective inspection of } \\
\text { equipment }\end{array}$ & 56.60 & 16 \\
\hline $\begin{array}{l}\text { Not to provide services to workers } \\
\text { through the implementation of } \\
\text { external roads }\end{array}$ & 52.77 & 29 \\
\hline $\begin{array}{l}\text { Asphalt plants are far from work } \\
\text { sites }\end{array}$ & 57.87 & 13 \\
\hline $\begin{array}{l}\text { Absence of workers or operators } \\
\text { of equipment }\end{array}$ & 45.53 & 59 \\
\hline Delays related to the project & 49.79 & 42 \\
\hline Control the traffic on the site & 46.81 & 52 \\
\hline Changes in site conditions & 50.64 & 39 \\
\hline Unexpected Earth Conditions & 54.04 & 25 \\
\hline $\begin{array}{l}\text { Insufficient data collection about } \\
\text { project site }\end{array}$ & 45.96 & 56 \\
\hline $\begin{array}{l}\text { Changes in site topography after } \\
\text { design }\end{array}$ & 45.53 & 59 \\
\hline $\begin{array}{l}\text { Night working conditions and } \\
\text { lack of sufficient work lights }\end{array}$ & 49.79 & 42 \\
\hline $\begin{array}{l}\text { Rework due to errors during } \\
\text { construction }\end{array}$ & 46.38 & 53 \\
\hline Theft of machines/ materials & 39.15 & 63 \\
\hline $\begin{array}{l}\text { Services for underground } \\
\text { construction such as telephone } \\
\text { and electricity lines, water pipes, } \\
\text { oil pipelines, and rainwater pipes }\end{array}$ & 12 \\
\hline Work environment / noise & \\
\hline
\end{tabular}

\subsection{The causes of delay from the consultant's point of view}

Table 5 shows all causes of delay and frequency of occurrence of each reason and its arrangement from the point of view of the consultant.

The top seven causes of delay identified by the consultants were:

The economic crisis of the country (F.I=12.77), Delays due to Cash flow problems faced by the contractor (F.I=11.06), Changes in the contract by the owner during the construction process (F.I $=10.64)$, Delay in monthly payments of contractor (F.I=10.64),insufficient and incomplete feasibility studies(F.I=10.64),Delays in materials test and obtaining the test results (F.I=9.79),The effects of weather, rain and high temperatures(F.I $=9.79)$. 
Table 5 Delay causes from the consultant' point of view

\begin{tabular}{|c|c|c|}
\hline & $\begin{array}{l}(\text { F.I) }(\%) \\
=\Sigma a \\
(\mathbf{n} / \mathbf{N}) * \\
100 / 5\end{array}$ & RANK \\
\hline \multicolumn{3}{|l|}{$\begin{array}{l}\text { Reasons related to the } \\
\text { Contractor }\end{array}$} \\
\hline Delay in delivering the site & 5.96 & 55 \\
\hline $\begin{array}{l}\text { Deficiencies in bidding by } \\
\text { contractors/causing calling them } \\
\text { to clarify it in the stage of the } \\
\text { award of the contract }\end{array}$ & 9.36 & 9 \\
\hline $\begin{array}{l}\text { Failure treatment the delays when } \\
\text { implementing the project }\end{array}$ & 6.81 & 44 \\
\hline $\begin{array}{l}\text { Delay in the consent of the owner } \\
\text { of the land to expand the road } \\
\text { through its }\end{array}$ & 6.38 & 51 \\
\hline $\begin{array}{l}\text { Poor Relationship between the } \\
\text { contractor and consultant }\end{array}$ & 7.23 & 39 \\
\hline $\begin{array}{l}\text { Cash flow problems faced by the } \\
\text { contractor }\end{array}$ & 11.06 & 2 \\
\hline $\begin{array}{l}\text { Inflation in material prices on the } \\
\text { market }\end{array}$ & 8.94 & 14 \\
\hline $\begin{array}{l}\text { Late deliveries of materials from } \\
\text { suppliers }\end{array}$ & 7.66 & 33 \\
\hline Supplier inefficiency & 6.81 & 44 \\
\hline Claims problems & 7.66 & 33 \\
\hline $\begin{array}{l}\text { Delay in activities during } \\
\text { implementation }\end{array}$ & 9.36 & 9 \\
\hline Cost estimates are not accurate & 9.36 & 9 \\
\hline Delay penalties & 8.09 & 21 \\
\hline \multicolumn{3}{|l|}{ Reasons related to the owner } \\
\hline $\begin{array}{l}\text { Changes in the contract by the } \\
\text { owner during the construction } \\
\text { process }\end{array}$ & 10.64 & 4 \\
\hline $\begin{array}{l}\text { Delay in monthly payments of } \\
\text { contractor }\end{array}$ & 10.64 & 4 \\
\hline $\begin{array}{l}\text { Problems in purchasing land } \\
\text { belonging to citizens }\end{array}$ & 7.23 & 39 \\
\hline $\begin{array}{l}\text { Misunderstandings with suppliers } \\
\text { and subcontractors }\end{array}$ & 8.09 & 21 \\
\hline $\begin{array}{l}\text { Insufficient and incomplete } \\
\text { feasibility studies }\end{array}$ & 10.64 & 4 \\
\hline Design problems & 8.09 & 21 \\
\hline \multicolumn{3}{|l|}{$\begin{array}{l}\text { Reasons related to the } \\
\text { consultant }\end{array}$} \\
\hline Error in site surveys & 8.09 & 21 \\
\hline $\begin{array}{l}\text { Error in approving the drawing by } \\
\text { the consultant }\end{array}$ & 7.66 & 33 \\
\hline $\begin{array}{l}\text { Inadequate authority for decision- } \\
\text { making by consultant }\end{array}$ & 5.96 & 55 \\
\hline Mistakes in Consultant drawings & 6.81 & 44 \\
\hline Weak consultant experience & 6.38 & 51 \\
\hline $\begin{array}{l}\text { Insufficient site information for } \\
\text { the consultant }\end{array}$ & 7.66 & 33 \\
\hline The inaccuracy of dimensions & 6.81 & 44 \\
\hline
\end{tabular}

\begin{tabular}{|c|c|c|}
\hline Reasons related to the materials & & \\
\hline $\begin{array}{l}\text { Shortage of materials during } \\
\text { implementation }\end{array}$ & 7.23 & 39 \\
\hline $\begin{array}{l}\text { Using materials does not conform } \\
\text { to specifications }\end{array}$ & 8.09 & 21 \\
\hline $\begin{array}{l}\text { Unexpected and repeated } \\
\text { adjustments in material } \\
\text { specifications during construction }\end{array}$ & 8.09 & 21 \\
\hline Material quality problems & 5.96 & 55 \\
\hline $\begin{array}{l}\text { Weakness in the site materials } \\
\text { management }\end{array}$ & 8.09 & 21 \\
\hline Rise in the prices of materials & 9.36 & 9 \\
\hline $\begin{array}{l}\text { Insufficient materials at the } \\
\text { beginning of the project, causing } \\
\text { delays }\end{array}$ & 7.66 & 33 \\
\hline $\begin{array}{l}\text { Do not put the material in its } \\
\text { proper place, causing difficulty in } \\
\text { transporting it inside the site }\end{array}$ & 9.36 & 9 \\
\hline Damage of materials & 7.23 & 39 \\
\hline $\begin{array}{l}\text { Disposal of road construction } \\
\text { waste }\end{array}$ & 8.51 & 19 \\
\hline $\begin{array}{l}\text { Delays in a materials test of and } \\
\text { obtaining the results }\end{array}$ & 9.79 & 7 \\
\hline \multicolumn{3}{|l|}{ Causes of external delay } \\
\hline $\begin{array}{l}\text { The effects of weather, rain and } \\
\text { high temperatures }\end{array}$ & 9.79 & 7 \\
\hline Low temperatures & 5.96 & 55 \\
\hline $\begin{array}{l}\text { Political decisions and political } \\
\text { realities }\end{array}$ & 11.06 & 2 \\
\hline $\begin{array}{l}\text { The economic crisis of the } \\
\text { country }\end{array}$ & 12.77 & 1 \\
\hline \multicolumn{3}{|l|}{$\begin{array}{l}\text { Reasons for labor and } \\
\text { equipment }\end{array}$} \\
\hline $\begin{array}{l}\text { Deficiency of skilled and } \\
\text { unskilled laborers }\end{array}$ & 8.09 & 21 \\
\hline Poor manpower productivity & 8.94 & 14 \\
\hline Injuries on site & 5.96 & 55 \\
\hline Labor strikes & 5.53 & 61 \\
\hline Absence of equipment & 8.09 & 21 \\
\hline Delayed delivery of equipment & 7.66 & 33 \\
\hline Shortage in equipment availability & 8.09 & 21 \\
\hline Insufficiency of operators & 6.81 & 44 \\
\hline $\begin{array}{l}\text { No adequate spaces for temporary } \\
\text { and permanent equipment }\end{array}$ & 5.96 & 55 \\
\hline $\begin{array}{l}\text { Ineffective inspection of } \\
\text { equipment }\end{array}$ & 8.94 & 14 \\
\hline $\begin{array}{l}\text { Not to provide services to workers } \\
\text { through the implementation of } \\
\text { external roads }\end{array}$ & 4.68 & 64 \\
\hline $\begin{array}{l}\text { Asphalt plants are far from work } \\
\text { sites }\end{array}$ & 8.94 & 14 \\
\hline $\begin{array}{l}\text { Absence of workers or operators } \\
\text { of equipment }\end{array}$ & 6.38 & 51 \\
\hline Delays related to the project & & \\
\hline
\end{tabular}




\begin{tabular}{|l|c|c|}
\hline Control the traffic on the site & 6.38 & 51 \\
\hline Changes in site conditions & 7.23 & 39 \\
\hline Unexpected Earth Conditions & 8.51 & 19 \\
\hline $\begin{array}{l}\text { Insufficient data collection about } \\
\text { project site }\end{array}$ & 6.81 & 44 \\
\hline $\begin{array}{l}\text { Changes in site topography after } \\
\text { design }\end{array}$ & 8.09 & 21 \\
\hline $\begin{array}{l}\text { Night working conditions and } \\
\text { lack of sufficient work lights }\end{array}$ & 5.53 & 61 \\
\hline $\begin{array}{l}\text { Rework due to errors during } \\
\text { construction }\end{array}$ & 6.81 & 44 \\
\hline Theft of machines/ materials & 8.09 & 21 \\
\hline $\begin{array}{l}\text { Services for underground } \\
\text { construction such as telephone } \\
\text { and electricity lines, water pipes, } \\
\text { oil pipelines, and rainwater pipes }\end{array}$ & 8.94 & 14 \\
\hline Work environment / noise & 5.11 & 63 \\
\hline
\end{tabular}

\section{Conclusions and recommendations}

The delay causes in highway construction projects in Iraq are discussed in a field survey. It studied the frequency index of the causes of delay from the contractors' and consultants' points of view.64 causes of delay were identified. The identified causes are classified into seven groups. Factors affecting the delay of highway projects were concluded:

\subsection{Contractor's and owner's view}

1- Political decisions and political realities and the economic crisis of the country. These two factors are repeated in the contractors'and owners'view, delay causes from the consultants'point of view. The reality and the unstable political situation in Iraq caused a volatile security situation, which leads to the closure of some roads and within cities, this situation leads to high cost of materials, lack of resources, delays in the arrival of raw materials to site and delays in the arrival of vehicles that transport asphalt mixtures to the site of the project,thus, will cause delay in the project.

2- Iraq is suffering from a terrible economic and financial crisis because of its dependence on oil as its sole source of foreign currency, in addition to the phenomenon of corruption pervasive in all aspects of the state and the policy of fiscal austerity adopted by the government, which caused the interruption of the implementation and completion of hundreds of infrastructure projects, such as road projects.

3-Delays in materials test and obtaining their results.This is due to the lack of technical devices entrusted with the inspection and the difficulty of obtaining construction materials conforming to the applicable specifications from natural quarries or from the asphalt supply plants. The weakness of quality control over the local product leads to dispersion of the contractor's effort and thus delays the project. On the other hand, it is necessary to establish an appropriate number of laboratories and adopt the field laboratory mechanism for the external and remote screens.
4-Delay in monthly payments of contractor.Difficulties in financing project by owner will result in delays in payment to contractors. This directly affects the completion of the project and cause time overrun as well as give rise to disputes between the various parties so owners should give special attention to pay the contractors on time.

5- Failure treatment the delays when implementing the project. The contractor's lack of experience in identifying the problems that occur during the implementation of the project, which cause delays and slow decisions and guidelines directly affect the delay. Therefore, Therefore, the contractor who has previous experience in the implementation of road projects should be selected.

6- Effects of weather, rain and high temperatures.It is meant to be a total or partial disruption of work due to rain, strong winds, or a significant drop in temperature, which prevents workers from doing their work.Therefore, the contractor must take into consideration the weather conditions when preparing the time plan for the project.

7- Delay in activities during implementation.There are several reasons to delay the project activities depending on the type of effectiveness, so the project manager should identify these reasons and deal with them quickly in order to reduce the total delay of the project.

\subsection{Causes of delay from the consultant's point of view}

In addition to the factors already appearing in clause 6.1,viz.Political decisions and political realities, the economic crisis of the country, delays in materials tests and obtaining their results, delay in monthly payments of contractor and the effects of weather, rain and high temperatures, other factors have appeared, according to the consultants' view which are:

1-Delays due to cash flow problems faced by the contractor.

Difficulties in financing projects develop because of lack of liquidity by the contractor. So the contractor must identify sources of funding and the need to develop a financial plan for each project beforehand. This helps predicting all non-nature conditions that occur during project implementation viz Lack of liquidity by the contractor, high worker wages, material prices or sudden breakdowns in equipment.

2-Changes in the contract by the owner during the construction process.

The existence of changes or amendments to the contract during the implementation (viz the change or modification of the designs or in the way of implementation or adding an item which is necessary or deleting an item which is not important) occurs most often because of the owner, so the impact of these changes on the project time should be assessed.

\section{References}

1. A. A. Salunkhe, R. S. Pail. IJRET, 3 (1), 543-547 (2014).

2. S.Ahmed, S. Azhar, P. Kappagantula,. Proc. 39th Annual Conf. ASC, Clemson Univ.(2003) . 
3. Ng S.T., R.M. Skitmore, K.C. Lam, A.W.C. Poon. I. J. P M. 22 (2) 139-146(2004).

4. M. Latham,. "Constructing the Team", HMSO, London, 8792.(1994).

5. H.A Awad., G.K Hindawi.. Journal of Babylon University, 14(4),483-494. 2007)

6.A.G. Bekr. JJCE. 9(2),149-162. (2015).

7.A.H, Al-Momani. International Journal of Project Management, 18 (3) (2000).

8. J. Al-Najjar, Islamic University, Gaza (2008

9. A, M Kasimu, D. I Abubakar, IJCRB. 4(2), 785- 794.

(2012)

10. Soo-Yong Kim et al ,6th ICCEPM .(2015)

11. A.S Msafiri. AJCE, 3(3), 51-63. (2015)

12. F. Remon, et al.Alexandria Engineering Journal, 55, (2), 1515-1539(2016).

13. Jeyakanthan et al,www.iiirr.ucalgary.ca/files/iiirr/190.

14. A .Nabil, A. S. Zaydoun IJET, 4 (2) 288-293 (2015),.

15. M. Ibrahim, B. Amund, D. Nabil. ASCE,.28:300310,(2012)

16. U. Sekaran,. Research methods for business: a skillbuilding approach. New York: John Wiley \& Sons (2003). 